\title{
Integrating phylogeographic and ecological niche approaches to delimitating cryptic lineages in the blue-green damselfish (Chromis viridis)
}

\author{
Shang Yin Liu ${ }^{\text {Corresp., } 1}$, Mao-Ning Tuanmu ${ }^{2}$, Rita Rachmawati ${ }^{3,4}$, Gusti Ngurah Mahardika ${ }^{5}$, Paul H Barber ${ }^{4}$ \\ 1 Department of Marine Biotechnology and Resources, National Sun Yat-Sen University, Kaohsiung, Taiwan \\ 2 Biodiversity Research Center, Academia Sinica, Taipei, Taiwan \\ 3 Center for Fisheries Research, Ministry of Marine Affairs and Fisheries, Jakarta, Indonesia \\ 4 Department of Ecology and Evolutionary Biology, University of California, Los Angeles, LA, United States \\ 5 The Indonesian Biodiversity Research Centre, Udayana University, Bali, Indonesia \\ Corresponding Author: Shang Yin Liu \\ Email address: syvliu@mail.nsysu.edu.tw
}

Species delimitation is challenging in sibling species/cryptic lineages because of the absence of clear diagnostic traits. However, integration of different approaches such as phylogeography and ecological niche comparison offers one potential approach to tease apart recently diverged lineages. In this study, we estimate the ecological niche divergence among lineages in Chromis viridis in a broad-scale phylogeographic framework to test whether the combination of these two approaches can effectively distinguish recently diverged lineages. Results from Cytb and Rag2 analyses identified two cryptic lineages ( $C$. viridis $A$ and $C$. viridis $B$ ) that diverged $\sim 3$ Myr ago. Estimates of ecological niche divergence with 11 environmental parameters across the broad geographic range of these lineages showed overlapping ecological niches and niche conservatism. However, regardless of the incongruence between genetic and ecological niche divergence, the substantial genetic divergence between the two clades of $C$. viridis in both mtDNA and nuclear loci strong suggest that they are cryptic taxa. 
1 Integrating phylogeographic and ecological niche approaches to delimitating cryptic lineages in

2 the blue-green damselfish (Chromis viridis).

3 Shang-Yin Vanson Liu ${ }^{1 *}$, Mao-Ning Tuanmu ${ }^{2}$, Rita Rachmawati ${ }^{3,4}$, Gusti Ngurah Mahardika ${ }^{5}$,

4 Paul H. Barber ${ }^{3}$

$5{ }^{1}$ Department of Marine Biotechnology and Resources, National Sun Yat-Sen University,

6 Kaohsiung, Taiwan

$7 \quad{ }^{2}$ Biodiversity Research Center, Academia Sinica, Taipei, Taiwan

$8{ }^{3}$ Department of Ecology and Evolutionary Biology, University of California Los Angeles, Los

9 Angeles, USA

${ }^{4}$ Center for Fisheries Research, Ministry of Marine Affairs and Fisheries, Jakarta, Indonesia

${ }^{5}$ The Indonesian Biodiversity Research Centre, Udayana University, Bali, Indonesia

12

*Correspondence: Shang Yin Vanson Liu, Department of Marine Biotechnology and Resources, National Sun Yat-Sen University, Kaohsiung, Taiwan. E-mail: syvliu@mail.nsysu.edu.tw

\section{Abstract}

Species delimitation is challenging in sibling species/cryptic lineages because of the absence of clear diagnostic traits. However, integration of different approaches such as phylogeography and ecological niche comparison offers one potential approach to tease apart recently diverged lineages. In this study, we estimate the ecological niche divergence among lineages in Chromis viridis in a broad-scale phylogeographic framework to test whether the combination of these two approaches can effectively distinguish recently diverged lineages. Results from Cytb and Rag2 analyses identified two cryptic lineages ( $C$. viridis $A$ and $C$. viridis $B)$ that diverged $~ 3 \mathrm{Myr}$ ago. Estimates of ecological niche divergence with 11 environmental parameters across the broad geographic range of these lineages showed overlapping ecological niches and niche conservatism. However, regardless of the incongruence between genetic and ecological niche 
27 divergence, the substantial genetic divergence between the two clades of $C$. viridis in both

28 mtDNA and nuclear loci strong suggest that they are cryptic taxa.

29

30

31

32

\section{Introduction}

Comparative phylogeography examines patterns of congruence in phylogenetic breaks across species distribution. It is built on the assumption that the processes driving lineage divergence, speciation, and the evolution of biodiversity mainly involves geographical, historical, and environmental factors that favor isolation and limit gene flow between populations (Avise, 2000; Rocha et al., 2007).

In the marine realm, phylogeographic studies frequently identify cryptic species, morphologically indistinguishable groups that have differences in neutral genetic markers that are equal or greater than those observed between species with diagnostic morphological traits (Knowlton, 1993). In some cases (e.g. Drew \& Barber, 2009; Drew et al., 2010; Hubert et al., 2012; Liu et al., 2012) such cryptic lineages are subsequently described as new species (Allen \& Drew, 2012; Liu et al., 2012; Allen, 2015), indicating that such cryptic lineages represent overlooked biodiversity.

Systematists use different characteristics to differentiate species, and the variation in these characteristics can arise at different times and rates during the process of lineage diversification (de Queiroz, 2007). However, species delimitation is particularly difficult in adaptive or recent radiations, when nascent species boundaries and their defining characteristics can be unclear (Puebla et al., 2008; Wagner et al., 2012; Victor, 2015). In such cases, integration of different approaches can increase the ability to detect recently separated lineages (Leache et al., 2009) 
50 and can provide stronger evidence for lineage separation when the results are concordant (Liu et

51 al., 2012; Allen \& Erdmann, 2012; Larkin et al., 2016).

52

53 While integrating morphological diversification and genetic divergence is relatively common in 54 addressing recent lineage diversification (e.g. Allen \& Drew, 2012; Allen \& Erdmann, 2012),

ecological diversification (i.e. niche divergence) is seldom used to differentiate cryptic lineages/species in the marine realm. Niche diversification is a foundation of speciation (Pyron et al., 2009). Therefore, if niche divergence leads to lineage differentiation in the process of populations adapting to new environments (Wiens, 2004; Wiens \& Graham, 2005), then a niche partitioning should be expected between lineages, particularly among recently diverged overlapping cryptic lineages identified in many phylogeographic studies.

To date, only a handful of studies have found niche divergence between cryptic marine taxa. For example, studies on deep-sea octocorals showed that niche partitioning between lineages is associated with the depth (Quattrini et al., 2013; Quattrini et al., 2017) and the marine cyanobacteria (genus Prochlorococcus) exhibits niche partitioning in associated with geography and environmental conditions. The absence of niche differentiation in the study of cryptic marine taxa is partially due to the lack of a centralized high-resolution spatial data representing both benthic and pelagic marine environments (Sbrocco \& Barber, 2013), resources that are now available.

Chromis viridis is widely distributed Indo-Pacific coral reef fish. Both juveniles and adults associate with Acropora corals where they school and feed on zooplankton in the water column above coral heads (Frédérich et al., 2009). Using phylogenetic analyses based on mtDNA 
73 variation, Froukh \& Kochzius (2008) found three cryptic lineages in C. viridis across four Indo-

74 Pacific localities, and Messmer et al. (2012) documented the presence of additional cryptic

75 lineages in the Great Barrier Reef. However, it is unclear how geographical and ecological

76 processes contribute to this nascent diversification.

77

78 To better understand the processes driving lineage diversification in C. viridis, we conducted a

79 broad scale phylogeographic study of $C$. viridis across its distribution range. We then estimated

80 ecological niche divergence between lineages in C. viridis in this phylogeographic framework to

81 test whether the combination of these two approaches can effectively distinguish recently

82 diverged lineages.

83

84 Materials \& Methods

85 Sample collection and DNA extraction

86 We collected 252 Chromis viridis between 2007 and 2017 from 15 locations across its Indo-

87 Pacific distribution (Table 1; Fig. 1). We collected specimens by hand net and clove oil, either by

88 scuba diving or snorkeling and preserved tissue samples (fin clips, a piece of muscle, or both) in

$8995 \%$ alcohol and stored at $4{ }^{\circ} \mathrm{C}$. Large fish were released following fin clipping, but individuals

90 too small for fin clipping were euthanized with clove oil and preserved whole in $95 \%$ ethanol.

91 The sampling depth of all specimens used in present study was less than $10 \mathrm{~m}$. This experiment

92 doesn't involve animal experiment and the field sampling process was complied with the

93 regulation drafted by the Animal Care and Use Committee of National Sun Yat-sen University.

94 Additionally, the permission to perform research activities in Indonesia was issued by the

95 Indonesian Government and the Ministry of Research and Technology under research permit

96 No.272/SIP/FRP/SM/VII/2013. 
97

98 We extracted genomic DNA from tissue fragments using Geneaid Tissue Genomic DNA mini

99 Kit (Geneaid Biotech, Taiwan) following manufacturers' protocol and eluted extracted DNA in

$100 \mathrm{TE}$ buffer and stored at $-20{ }^{\circ} \mathrm{C}$ until amplification by polymerase chain reaction (PCR).

101

102 Amplification of genetic markers

103

104 We amplified a portion of the mitochondrial cytochrome b (Cytb) gene using universal primers

105 GluDG-L and H16460 (Palumbi, 1996). PCRs reactions were $30 \mu \mathrm{L}$ in volume, containing 10-40

106 ng template DNA, $3 \mu \mathrm{L} 10 \mathrm{X}$ buffer, $0.2 \mathrm{~m} M$ dNTPs, $1.5 \mathrm{~m} M \mathrm{MgCl}_{2}, 10 \mathrm{~m} M$ each primer, and

1070.2 units of Taq polymerase (MDbio, Taipei). The thermocycling profile consisted of initial

108 denaturation at $94{ }^{\circ} \mathrm{C}$ for $2 \mathrm{~min}$, followed by 41 cycles of denaturation at $94{ }^{\circ} \mathrm{C}$ for $30 \mathrm{~s}$,

109 annealing at $57^{\circ} \mathrm{C}$ for $30 \mathrm{~s}$, and extension at $72{ }^{\circ} \mathrm{C}$ for $40 \mathrm{~s}$, concluding with a final extension at

$11072^{\circ} \mathrm{C}$ for $2 \mathrm{~min}$.

111

112 Because mitochondrial and nuclear genes can have very different histories, we also amplified the

113 nuclear recombination-activating (Rag2) gene for a subset of samples that represented distinct

114 clades recovered in the mtDNA, using primers RAG2F and RAG2R (Westneat \& Alfaro, 2005).

115 PCR reactions were as above, except that we used a $5 \mathrm{mM} \mathrm{MgCl}$ concentration and the following

116 thermocycling parameters: 39 cycles of denaturation at $94{ }^{\circ} \mathrm{C}$ for $30 \mathrm{~s}$, annealing at $56{ }^{\circ} \mathrm{C}$ for 30

$117 \mathrm{~s}$, and extension at $72{ }^{\circ} \mathrm{C}$ for $40 \mathrm{~s}$, and a final extension at $72{ }^{\circ} \mathrm{C}$ for $2 \mathrm{~min}$.

118

Peer] reviewing PDF | (2019:05:37980:1:1:NEW 25 Jun 2019) 
119 The nucleotide sequences of the PCR products of both loci were determined using ABI 3730XL

120 automated sequencer (Carlsbad CA, U.S.A.) by Genomics (https://www.genomics.com.tw).

121 Nucleotide sequences were assembled and edited using the SEQUENCHER version 4.2 software

122 (Gene Code, Ann Arbor MI, U.S.A.). Sequences were uploaded to GenBank under the accession 123 number MH743228-MH743691.

\section{Phylogenetic analyses}

126 Prior to any analyses, we aligned DNA sequences from each gene region in Clustal W

127 (Thompson et al., 1994) and exported these sequences to MEGA 6 (Tamura et al., 2013) to

128 visually inspect all alignments for accuracy. To quantify genetic diversity measures, we

129 calculated standard genetic diversity indexes including haplotype diversity $(h)$ and nucleotide

130 diversity $(\pi)$ in Arlequin 3.5 (Excoffier \& Lischer, 2010). We then inferred phylogenetic trees

131 from each individual locus using maximum likelihood (ML) and Bayesian inference performed

132 on the CIPRES Science Gateway (Miller et al., 2010), and in BEAST 2.4.5 (Bouckaert et al.,

133 2014). We conducted the ML analyses in RAxML version 8.1.24 (Stamatakis, 2014) using the

134 GTR + G substitution model which selected by MEGA 6 (Tamura et al., 2013) as best-fit

135 substitution model. For Bayesian inference, we used MrBayes version 3.2.2 (Ronquist et al.,

136 2012), implementing two parallel runs of four simultaneous Markov chains for 10 million

137 generations, sampling every 1000 generations and using the default parameters. Run parameters

138 employed unlinked substitution models, rated heterogeneity models, and based frequencies

139 across partitions. In the Bayesian analyses the first one million generations (10\%) were discarded

140 as burn-in, based on log- likelihood tree scores. Meanwhile, the convergence diagnostic was

141 applied and the stop probability was set to 0.01. Nodal support was evaluated individually for all 
142 trees using non- parametric bootstrapping with 1000 maximum likelihood replicates as employed

143 in RAxML (Stamatakis, 2014), and by calculation of posterior probabilities as employed in

144 MrBayes. Lastly, we generated a median-joining haplotype networks based on Cytb and Rag2

145 sequence datasets by using Popart 1.7 (http://popart.otago.ac.nz).

146

147 To date the ages of Chromis viridis clades, we arbitrarily subsampled 2 Cytb sequences from 148 each clade; we also included two outgroups, including Chromis atrilobata (AY208524.1) and 149 Chromis multilineata (AY208533.1) to calibrate date ranges as these two taxa diverged 3.1Mya, 150 (Quenouille et al., 2004). We created the XML BEAST input file using the software BEAUti 151 v.1.8.2. (as implemented in BEAST), with the setting of 50 million generations under the 152 uncorrelated relaxed clock model, and sampling trees once every 1000 generations. To test for 153 inter-run variation, we conducted two independent runs in BEAST 2.4.5 (Bouckaert et al., 2014), 154 and then checked these runs for convergence with the software Tracer v1.5 (available at 155 http://tree.bio.ed.ac.uk/software/tracer/). After discarding the $20 \%$ burn-in, we pooled the 156 remaining tree samples from the two runs into a combined file to calculate the maximum clade 157 credibility tree. From this tree, we calculated the posterior mean divergence ages and 95\% 158 credibility intervals (CI) for all nodes using Tree Annotator v1.8.2 (implemented in the BEAST 159 package). To compare the similarity of two gene tree topologies, Phylo.io software (Robinson et 160 al., 2016) was used.

161 162

\section{Ecological niche characterization and comparison}


164 To characterize the ecological niches of $C$. viridis ( $C$. viridis Clade A) and potential cryptic 165 species (C. viridis Clade B), we obtained geophysical, biotic, and environmental data layers for 166 global sea surface from Bio-ORACLE (downloaded on Feb. 20 ${ }^{\text {th }}, 2018$; Tyberghein et al., 2012; 167 Assis et al., 2018). We then extracted the values of those factors for the locations where $C$. 168 viridis samples were collected. We excluded factors such as ice thickness and sea ice 169 concentration from our analyses because all sample sites were tropical and ice free. 170

171 To explore niche differentiation between $C$. viridis Clade $\mathrm{A}$ and $C$. viridis Clade $\mathrm{B}$, we first 172 compared the values of individual environmental factors between $C$. viridis Clade A and Clade B 173 sampling sites using Mann-Whitney tests. Next, we plotted niche differences in a two174 dimensional non-metric multidimensional scaling (NMDS) space based on the Euclidean 175 dissimilarity of those factors. Due to the different units of the environmental factors, we 176 standardized factor values before running the NMDS analysis. Lastly, we tested equivalency of 177 ecological niches between the species based on environmental factors of $C$. viridis Clade A and 178 Clades B sampling locations in a Principle Components Analysis framework. Due to potential 179 correlations among environmental factors, we ran the principal component analysis (PCA) on all 180 environmental factors and then used the resulting principal components to define niches of the 181 species. Because C. viridis mainly occur in coral reefs, we restricted our PCA to regions (grid 182 cells) where the maximum depth was equal or less than $50 \mathrm{~m}$ based on the bathymetry data 183 obtained from MARSPEC (http://www.marspec.org/; Sbrocco \& Barber, 2013). To make the 184 spatial resolution of the bathymetry data layer, which is originally at 30-by-30-arc second 185 resolution, consistent with the Bio-ORACLE data, we upscaled it to 5-by-5-arc minute resolution 
186 with each pixel value in the upscaled data layer being the maximum value over 10x10 original 187 pixels within that new pixel.

188

189 To measure niche similarity between $C$. viridis Clade A Clade B, we calculated the $D$ and $I$ 190 statistics developed by Warren et al. (2008). These two indices range from 0 and 1 with higher 191 values indicating more similar niches. To test for niche equivalency between these two cryptic 192 lineages of $C$. viridis, we compared the observed similarity values to null distributions of 193 similarity obtained through a randomization procedure under a hypothesis of an identical niche 194 (Warren et al., 2008), using the "dismo" package in R (version 3.4.2).

195

196

197

198

199

200

201 202 203 204 205 206 207 208 variable sites during computation in Arlequin 3.5.

\section{Results}

We sequenced 911 base pairs of mitochondrial Cytb, and 743 base pairs of nuclear gene (Rag2, 743 bp) from 248 individual Chromis viridis, representing 15 locations across the Indo-Pacific (Fig. 1). In total, there were 135 unique haplotypes of Cytb; nucleotide diversity $(\pi)$ ranged from 0.0033 to 0.0544 , and haplotype diversity $(h)$ ranged from 0.8824 to 1 among locations. For Rag2, 30 samples would not amplify, resulting in a total of 218 Rag2 sequences, representing fourteen unique haplotypes after omitting those sites with ambiguity codes (e.g. Y and K), additionally, there were 40 parsimony informative sites after alignment and 26 (heterozygotes) out of 40 were contained ambiguous signals. The nucleotide diversity $(\pi)$ and haplotype diversity (h) of Rag2 ranged from 0 to 0.0154 and 0.9933 to 1 , respectively (Table 1 ). These two genetic diversity indexes could be over-estimated since those ambiguous sites were been considered as 
210 The maximum likelihood tree based on Cytb gene revealed three deeply divergent lineages 211 within C. viridis; Clade A, Clade A-1, and Clade B (Fig. 2). In contrast, the corresponding Rag2

212 likelihood tree only differentiated Clades A and B, with no additional divergence within Clade 1.

213 However, Clades A and B were not concordant across Cytb and Rag2; four mtDNA Clade B 214 samples, one from Komodo and three from Lizard Island, clustered with Clade A based on Rag2. 215 Additionally, one sample from Komodo contained a Clade B Rag2 sequence, but a Clade A Cytb 216 sequence (Table S1).

217

218 Whether based on Cytb or Rag2, all Clade B haplotypes came from only three locations; Lizard 219 Island on the Great Barrier Reef, Komodo Island in Indonesia, and the island of Fiji. In contrast, 220 Clade A occurred broadly throughout the Indo-Pacific, including all three Clade B localities. 221 Based solely on mtDNA, Clade A was further divided into two clades; Clade A was broadly 222 distributed, and Clade A-1 was restricted to the Red Sea, although the Red Sea clade was not 223 recovered in the Rag2 phylogeny. The general tree topology of these two genes was highly 224 similar (Figure S1), except the Clade A-1 and those samples clustered with it, which can be 225 revealed only by Cytb.

226

227

228 The patterns from the median joining network tree were identical to the phylogenetic trees based 229 on either Cytb and Rag2. However, a few individuals assigned to Clade B based on Cytb 230 clustered with Clade A based on their Rag2 sequences (Fig. 2). 
232 Results from BEAST indicated that $C$. viridis Clade A and Clade B diverged approximately 233 3Mya (95\% HPD: 0.631-6.291 Mya), with the divergence between Clade A and A-1 dating to 234 1.165 Mya (95\% HPD: 0.247-2.49 Mya), and crown age of A-1 (Red Sea) was dated 0.138 Mya 235 (95\% HPD: 0.013-0.332 Mya) (Fig. 3).

236

237 Niche divergence tests

238

239 Results spanning 11 environmental factors (Table 2) showed no significant difference in 240 ecological niche parameters of Clade A or Clade B of C. viridis. Moreover, there was also no 241 significant environmental difference between the locations where two clades co-occur and those 242 where only Clade B occurs (Table 2), suggesting that the environmental factors cannot explain 243 why Clade B co-occurs with Clade A at some locations, but not at others.

245 The NMDS analysis also showed a lack of niche differentiation. The first two NMDS axes 246 explained $86.7 \%$ of the variation in the 11 environmental factors across the 15 sampling sites.

247 The three sampling sites where $C$. viridis B occurs fall at the center of the convex hull of all 248 sampling sites in the two-dimensional NMDS space (Fig. 4), indicating complete niche overlap 249 between Clades A and B. The first four principal components of the environmental factors, 250 which were standardized before the analysis, had eigenvalues higher than 1 . Together they 251 explain about $83.1 \%$ of the total variation across all the grid cells with the maximum water depth 252 less than or equal to $50 \mathrm{~m}$. Based on the component scores corresponding to the locations where

253 Clades A and B were found, niche similarity indices were high, with $D=0.841$ and $I=0.973$.

254 Moreover, niche equivalency tests showed that none of the two values were significantly 
255 different from the values obtained through a randomization process under the hypothesis of an 256 identical niche ( $P$-values for $D$ and $I$ were 0.311 and 0.294 , respectively).

257

258

259

260

261

262

263

264

265

266

267

268

269

270

27

272

273

274 275

276

\section{Origin of lineage diversification}

\section{Discussion}

Range-wide phylogeographic analyses of the blue green damselfish, $C$. viridis revealed two divergent lineages in both mitochondrial Cytb and nuclear Rag2 DNA sequence data. These cryptic lineages were first reported by Froukh and Kochzius (2008) in the Coral Triangle and Red Sea, and subsequently by Messmer et al. (2012) who examined Australia and French Polynesia. However, these studies each only covered a fraction of the geographic range of $C$. viridis. By examining patterns across its entire range, this study shows that these cryptic lineages of $C$. viridis are sympatric over a portion of their Pacific range.

Moreover, previous studies (Froukh \& Kochzius, 2008; Messmer et al., 2012) only used mtDNA markers, providing incomplete insights into genetic structure due to its maternal inheritance (Prugnolle \& De Meeûs, 2002; Daly-Engel et al., 2012). By sequencing both mtDNA and nuclear markers, this study confirms the presence of two cryptic clades in C. viridis, Clades A and B. These clades diverged approximately 3 Mya similar to the divergence of C. atrilobata and C. multilineata that were separated by Isthmus of Panama (Domingues, et al. 2005). Given the depth of this divergence and the largely concordant differentiation of Clade A and B in Cytb and Rag2, it is likely that these two lineages represent distinct species, raising interesting questions about the sympatry of Clades A and B in part of their range. 
278 Although the divergence of Clades $\mathrm{A}$ and $\mathrm{B}$ of $C$. viridis is clear, the origin of this divergence is

279 not. Within the Indo-Pacific region, the "Indo-Pacific Barrier" has been considered as a soft

280 barrier that could be the main driving force of marine biological provinces in this region (Gaither

281 et al., 2011). Barber \& Bellwood (2005) and Cowen \& Bellwood (2013) examined the

282 importance of this barrier by evaluating the extent of temporal concordance in vicariance in three

283 prominent families of reef fish, including Labridae, Pomacentridae and Chaetodontidae. Both

284 studies showed that the isolation effect of Indo-Pacific barrier on the widely distributed fishes

285 mainly occurred mostly between end Miocene and Early Pliocene (2-6 Myr), and the majority of

286 vicariance events occurred in a narrow time interval at approximately $2.5 \mathrm{Myr}$.

287

288 The date of divergence of Clade A and B broadly conforms to the onset of Plio-Pleisetocene sea

289 level fluctuations (Voris, 2000). However, Clade B populations of C. viridis occur on islands

290 surround by deep water where lowered sea levels would not result in land barriers that promote

291 vicariance, unlike other marine taxa distributed on opposite sides of the Sunda Shelf (e.g. Barber

292 et al., 2006; Crandall et al., 2008; DeBoer et al., 2014a, 2014b; Crandall et al., 2014; Waldrop

293 et al., 2016; Simmonds et al., 2018). Given the Indo-Pacific wide range of C. viridis and a

294 divergence time between two cryptic clades dating to 3Mya, isolation across the Indo-Pacific

295 Barrier is the most likely driver of divergence between Clades A and B. Under this scenario,

296 Clade A would be an Indian Ocean clade that has expanded into the Pacific, where it now

297 overlaps with the Pacific Clade B, a process previously noted in Neritid snails (Crandall et al., 298 2008).

299

Peer] reviewing PDF | (2019:05:37980:1:1:NEW 25 Jun 2019) 
300 An alternate, but not mutually exclusive explanation for divergence of Clade B comes from

301 recent studies of coral associated marine taxa. Similar to phytophagus insects that undergo

302 ecological divergence associated with host switching (Berlocher \& Feder, 2002; Hébert et al.,

303 2016), recent studies from the marine realm demonstrate that changes in coral host taxa can

304 promote lineage divergence, potentially leading to speciation (Simmonds et al., 2018). Samples

305 were not collected in a way that allows us to test this hypothesis, but future studies separating

306 samples by coral host to determine whether individuals from Clades A and B exist in mixed

307 schools in sympatric populations, and if so, whether those schools are associated with different

308 coral hosts.

309

310 The geographic distribution of Clade B is curious in that it is observed in Komodo, but not in

311 other populations in the Lesser Sunda Islands (e.g. Amed, Nusa Lembongan). Similarly, Clade B

312 is observed on the Great Barrier Reef and Fiji, but not in New Caledonia, a population located

313 between these too population. One explanation for this disjunct distribution is that Clade B

314 individuals are relatively rare, and that greater sampling intensity would reveal Clade B

315 haplotypes in adjacent ranges, as would be expected. Alternatively, it is possible that Clade A is

316 gradually displacing Clade B populations, and the areas of sympatry represent locations where

317 this process is incomplete. Similar arguments were made to explain sympatry of highly divergent

318 clades of marine snails in the Pacific Ocean (Crandall et al., 2008).

319

320 In contrast to the divergence of Clade A and B, the divergence of Clade A-1, unique to the Red

321 Sea, is more easily interpreted as the result of vicariance. The Red Sea is a semi-enclosed basin

322 that is frequently invoked in driving population differentiation of reef organisms between the 
323 Red Sea and Indian Ocean (Dibattista et al., 2013). Additionally, the 95\% HPD of Red Sea

324 Clade is ranged from 0.013 to 0.332 Mya which aligns with the most recent closure of the Red

325 Sea (Siddall et al., 2003). However, while mitochondrial DNA shows a well-supported Red Sea

326 sub clade within C. viridis Clade A, this clade is not confirmed with nuclear Rag2 sequence.

327 Lack of concordance between the mtDNA and nuclear phylogenies is not surprising. First, there

328 is substantially more genetic variation in the mtDNA sequences because DNA repair

329 mechanisms are less efficient in mtDNA, resulting in much higher substitution rates (Alexeyev et

330 al., 2013). Second, because mitochondrial genome is maternally inherited and haploid, its

331 effective population size is one-fourth that of a nuclear gene, meaning that lineage sorting occurs

332 more rapidly in mtDNA (Hare, 2001). Thus, mitochondrial gene trees have a substantially higher

333 probability of accurately recovering recently divergence lineages with short internode distances

334 than do nuclear genes (Moore, 1995). Given that the Red Sea mtDNA clade only dates to 0.138

335 Mya, it is unsurprising that divergence in this region is not recovered in the Rag2 sequences.

336 Thus, while the Red Sea population is clearly a sub-population of C. viridis Clade A, it is

337 unlikely a cryptic species, like Clades A and B.

338

339 Cryptic Species

340 Many phylogeographic studies in the Indo-Pacific find highly divergent clades, often with

341 regions of sympatry (i.e. Barber et al., 2002, 2006; Crandall et al., 2008; Gaither et al., 2011;

342 Liu et al., 2012, DeBoer et al., 2014; Bowen et al., 2016). In many cases, these cryptic clades

343 may represent cryptic species, similar to Liu et al. (2012) where a divergent clade of

344 Pomacentrus coelestis in Micronesia was subsequently described as a new species (Liu et al.,

345 2013). The concordant phylogeographic patterns in mtDNA and nuclear DNA, and the depth of 
346 this divergence suggests that Clades $\mathrm{A}$ and $\mathrm{B}$ of $C$. viridis may represent two cryptic species with

347 different geographic ranges; Clade A is a widely distributed Indo-Pacific, while Clade B is only

348 found in Lizard Island, Komodo, and Fiji.

349

350 Comparison of Cytb and Rag2 trees revealed a limited amount of discordance. Given the

351 relatively recent divergence, one potential explanation for this pattern is incomplete lineage

352 sorting (Tang et al., 2012). Incomplete lineage sorting is the simplest explanation for individuals

353 with Clade B C. viridis haplotypes in the mtDNA tree having Clade A C. viridis Rag2 sequences

354 (Table S1). However, incomplete lineage sorting could not explain the sequence of komo4

355 clustered with $C$. viridis clade B in the Rag2 tree but clustered with $C$. viridis Clade A in the

356 mtDNA tree. The later finding could likely explain by the consequence of hybridization.

357

358 Hybridization is in C. viridis is unsurprising as closely related Pomacentrids often have

359 overlapping geographic distributions, co-occur in the same microhabitats (e.g. colonies of

360 branching corals) (Randall et al., 1977), and spawn sympatrically (Jan, 1996). Hybridization has

361 been observed in several sibling species of damselfish, including Abudefduf

362 abdominalis $\times$ Abudefduf vaigiensis (Coleman et al., 2014), Amphiprion

363 chrysopterus $\times$ Amphiprion sandaracinos (Gainsford et al., 2015), Amphiprion

364 mccullochi $\times$ Amphiprion akindynos (van der Meer et al., 2012), Dascyllus carneus $\times D$.

365 marginatus (DiBattista et al., 2015), and D. reticulatus $\times$ D. aruanus (He et al., 2017). As such,

366 both hybridization and incomplete lineage sorting are likely responsible for the discordant

367 patterns in the two markers. 
Incongruence between genetic and ecological niche divergence

370

371 Hutchinson (1978) proposed that two species cannot occupy the same ecological niche, yet niche

372 conservatism predicts that closely related taxa retain ancestral ecological affiliations and persists

373 in similar environments (Lord et al., 1995; Webb et al., 2002; Wiens \& Graham, 2005).

374 Allopatric sister taxa are often characterized by niche conservatism, but because geographic

375 isolation drives speciation (Peterson et al., 1999; Peterson et al., 2001; Kozak \& Wiens, 2006)

376 sibling species can't compete for the same niche space, because, by definition, they have non-

377 overlapping geographic ranges.

378

379 The alternative to niche conservatism is niche divergence, in which sister taxa occupy different 380 niches (Dayan \& Simberloff, 2005). Niche divergence is typically associated with sympatric 381 speciation as diversification results from reduction in gene flow associated with divergence in 382 traits with ecological function (e.g. habitat segregation, pollinator divergence, behavioral 383 changes, phenological shifts, and mating system shifts). Under niche divergence, young sister 384 species with high degrees of range overlap should ecologically diverge (Dayan \& Simberloff, 385 2005; Davies et al., 2007). While ecological modeling and phylogenetics are commonly 386 integrated to understand the relationship between evolutionary and ecological divergence of 387 sibling species (Kalkvik et al., 2012; Schorr et al., 2012), few studies examine the intra-specific 388 (cryptic lineage) level (Gutiérrez-Tapia \& Palma, 2016).

390 Our results show that Clade A and B of C. viridis are sympatric, with Clade B haplotypes 391 occurring only at three localities. There are two possible explanations for this pattern. First, 
392 lineage diversification could have occurred in sympatry, as seen in Indo-Pacific coralivorous 393 snails (Simmonds et al., 2018). Alternatively, diversification could have occurred in allopatry 394 with secondary overlap in geographic ranges as proposed for neritid snails (Crandall et al., 395 2008). Niche comparisons based on 11 environmental factors showed that Clade A has a broader 396 ecological niche than Clade B does (Fig 4). Despite this difference, there is no significant niche 397 differentiation between these two lineages. As such, diversification is more likely to have arisen 398 with niche conservatism rather than niche differentiation.

400 Given the absence of niche differentiation, our results suggest that the diversification of Clades 401 A and B most likely occurred in allopatry, and that secondary contact is the most likely 402 explanation for their current distribution. If true, niche conservatism could help explain the 403 disjunct distribution of Clade B. Under this scenario, Clade A and Clade B would compete for 404 the same niche space when they occur in sympatry. If Clade A is a superior competitor, it would 405 gradually displace Clade B populations, potentially explaining the relative rarity of Clade B 406 haptotypes and their disjunct distributions.

407

408 Alternatively, Pyron et al. (2015) suggested that niche conservatism could result from soft 409 allopatry where there is low environmental heterogeneity. As noted above, the shallow Sunda 410 and Sahul continental shelves exposed during low sea level stands (Voris 2000), forming long 411 land bridges that restricted larval exchange between the tropical Indian Ocean and the western 412 Pacific (reviewed in Randall, 1998). However, because deep water passages in what is modern 413 day Indonesia remained open, and because low sea level stands were intermittent, the Indo414 Pacific Barrier has been considered a soft dispersal barrier for marine taxa (Cowman \& 
415 Bellwood, 2013). The 11 environmental factors we used to define the niches of the two lineages 416 of $C$. viridis only reflect broad-scale environmental conditions. However, there could be subtle

417 variation in environmental factors, or variation could occur at finer scales (e.g. microhabitat), 418 resulting in soft-allopatric divergence.

420 It is important to note that the broad environmental variation we examine does not capture the 421 potential diet shifts observed in sibling species (Goodheart et al., 2017), novel traits (Liu et al., 422 2018), and/or micro habitat preference (Whitney et al., 2018) that could act to drive or reinforce 423 lineage diversification. The latter is particularly intriguing given recent studies demonstrating 424 ecological speciation resulting from shifts in coral hosts (Simmonds et al., 2018). Further studies 425 such as stable isotope analysis and detailed morphological examinations in a phylogenetic 426 framework are needed to better understand the ecological and morphological divergence between 427 these two lineages.

428

429

430

431 Conclusions

432 Although cryptic diversification in widespread marine species is common (Hubert et al., 2012), 433 phylogeographic studies typically ignore the potential role of ecological niche partitioning on 434 lineage diversification. The present study shows evolutionary divergence between two lineages 435 of $C$. viridis that have overlapping ecological niches, supporting niche conservatism. It is unclear 436 whether this pattern results from allopatric divergence with secondary contact, or from subtle 437 differentiation in ecological niches not captured by the broad scale environmental data used to 438 compare ecological niches. Regardless of the origins, the substantial genetic divergence between 439 the two clades of $C$. viridis in both mtDNA and nuclear loci strong suggest that they are cryptic 
440 taxa. Because $C$. viridis is highly exploited in the aquarium trade (Wabnitz, 2003), we suggest

441 that a higher conservation priority needs to be given on the Clade B lineages restricted to

442 Australia, Indonesia, and Fiji to protect this unique genetic lineage.

443

444

445

446

447

448

449

450

451

452

453

454

455

456

457

458

459

460

461

462

463

464

465

466

\section{Acknowledgements}

We thank Dr. S. Cheng, Dr. M-J Ho, Dr. Y-R Cheng, F-T Chang, N. Narendra and A. Sembiring for their assistant in the field, and Dr. V. Messmer, Dr. B. Frédérich, Dr. F. Borsa, Professor S. Planes and S. Johnson for sharing tissue samples. Special thanks to A. C. Bentley, for his curatorial help on obtaining tissue samples from Ichthyology session of Kansas University. This study was funded by Ministry of Science and Technology, Taiwan (Grant Number: MOST 1062611-M-110-009). All applicable international, national, and institutional guidelines for the use of animals were followed. We declare no conflict of interest.

\section{References}

Alexeyev M, Shokolenko I, Wilson G, LeDoux S. 2013. The maintenance of mitochondrial DNA integrity-critical analysis and update. Cold Spring Harbor Perspectives In Biology 5: a012641 
467 Allen GR, Erdmann MV. 2012. Reef fishes of the East Indies. Perth, Australia: Tropical Reef

468 Research

469

470 Allen GR, Drew J. 2012. Pomacentrus maafu a new species of damselfish from the Southwest

471 Pacific. Aqua: International Journal of Ichthyology 18: 171-180

472

473 Allen GR, Erdmann MV, Kurniasih E. 2015. Chrysiptera caesifrons, a new species of 474 damselfish (Pomacentridae) from the south-western Pacific Ocean. Journal of the Ocean Science 475 Foundation 15: 16-32

476

477

Assis J, Tyberghein L, Bosch S, Verbruggen H, Serrão EA, De Clerck O. 2018. Bio478

ORACLE v2.0: Extending marine data layers for bioclimatic modelling. Global Ecology 479 Biogeography 27: 277-284

480

481

Avise JC. 2000. Phylogeography: the history and formation of species. Cambridge, MA:

482

Harvard university press.

483

484

Avise JC. 2009. Phylogeography: Retrospect and prospect. Journal of Biogeography 36: 3-15

485

486

Barber PH, Palumbi SR, Erdmann MV, Moosa MK. 2002. Sharp genetic breaks among 487 populations of Haptosquilla pulchella (Stomatopoda) indicate limits to larval transport: patterns, 488 causes, and consequences. Molecular Ecology 11: 659-674

489 
490 Barber PH, Palumbi SR, Erdmann MV. 2006. Comparative phylogeography of three

491 codistributed stomatopods: origins and timing of regional lineage diversification in the Coral

492 Triangle. Evolution 60: 1825-1839

493

494

495

Berlocher SH, Feder JL. 2002. Sympatric speciation in phytophagous insects: moving beyond controversy? Annual Review of Entomology 47: 773-815

496

497

498

Bowen BW, Karl SA, Pfeiler E. 2007. Resolving evolutionary lineages and taxonomy of bonefishes (Albula spp.). In: Ault, J.S. (Ed.), Biology and Management of the World Tarpon.

500

501

Bouckaert R, Heled J, Kühnert D, Vaughan T, Wu C-H, Xie D, Suchard MA, Rambaut

502 A, Drummond AJ. 2014. BEAST 2: A Software Platform for Bayesian Evolutionary Analysis. 503 PLoS Computational Biology 10: e1003537

504

505

506

Webb CO, Ackerly DD, McPeek MA, Donoghue MJ. 2002. Phylogenies and community ecology. Annual review of ecology and systematics 33: 475-505

507

508

Coleman RR, Gaither MR, Kimokeo B, Stanton FG, Bowen BW, Toonen RJ. 2014. Large-

509 scale introduction of the Indo-Pacific damselfish Abudefduf vaigiensis into Hawai'i promotes genetic swamping of the endemic congener A. abdominalis. Molecular Ecology 23: 5552-5565

511

512 Cowman PF, Bellwood DR. 2013. The historical biogeography of coral reef fishes: global 513 patterns of origination and dispersal. Journal of Biogeography 40: 209 - 224 
515 Crandall ED, Frey M, Grossberg RK. Barber, PH. 2008. Contrasting demographic history

516 and phylogeographical patterns in two Indo-Pacific gastropods. Molecular Ecology 17: 611-626

517

518 Crandall ED, Treml EA, Liggins L, Gleeson L, Yasuda N, Barber PH, Gert W, Riginos, C.

519 2014. Return of the ghosts of dispersal past: historical spread and contemporary gene flow in the 520 blue sea star Linckia laevigata. Bulletin of Marine Science 90: 399-425

521

522

Daly-Engel TS, Seraphin KD, Holland KN, Coffey JP, Nance HA, Toonen RJ, Bowen BW.

523

2012. Global phylogeography with mixed-marker analysis reveals male-mediated dispersal in the

524 endangered scalloped hammerhead shark (Sphyrna lewini). PLoS One 7: e29986

525

526

527

Dayan T, Simberloff D. 2005. Ecological and community-wide character displacement: the next generation. Ecology Letters 8: 875-894

528

529

Davies TJ, Meiri S, Barraclough TG, Gittleman JL. 2007. Species co-existence and character 530 divergence across carnivores. Ecology Letters 10: 146-152

531

532

DeBoer TS, Naguit MR, Erdmann MV, Ablan-Lagman MCA, Ambariyanto, Carpenter 533 KE, Toha AHA, Barber PH. 2014a. Concordant phylogenetic patterns inferred from 534 mitochondrial and microsatellite DNA in the giant clam Tridacna crocea. Bulletin of Marine 535 Science 90: 301-329 
E, Toha AHA, Barber PH. 2014b. Concordance between phylogeographic and biogeographic boundaries in the Coral Triangle: conservation implications based on comparative analyses of multiple giant clam species Bulletin of Marine Science 90: 277-300

541

542

de Queiroz K. 2007. Species concepts and species delimitation. Systematic Biology 56: 879 $543 \quad 886$

544

545

DiBattista JD, Berumen ML, Gaither MR, Rocha LA, Eble JA, Choat JH, Craig MT, 546 Sinclair-Taylor TH, Bowen BW. 2013. After continents divide: comparative phylogeography of reef fishes from the Red Sea and Indian Ocean. Journal of Biogeography 40: 1170-1181.

548

549

DiBattista JD, Rocha L A, Hobbs J-PA, He S, Priest MA, Sinclair-Taylor

550

TH, Bowen BW, Berumen ML. 2015. When biogeographical provinces collide: hybridization 551 of reef fishes at the crossroads of marine biogeographical provinces in the Arabian Sea. Journal

552 of Biogeography 42: 1601- 1614

553

554

Drew JA, Barber PH. 2009. Sequential cladogenesis of Pomacentrus moluccensis (Bleeker, 555 1853) supports the peripheral origin of marine biodiversity in the Indo-Australian Archipelago. Molecular Phylogenetics and Evolution 53: 335-339

557 
558 Drew JA, Allen GR, Erdmann MV. 2010. Congruence between genes and color morphs in a

559 coral reef fish: population variability in the Indo-Pacific damselfish Chrysiptera rex (Snyder, 560 1909). Coral Reefs 29: 439-444

561

562 Frédérich B, Fabri G, Lepoint G, Vandewalle P, Parmentier E. 2009. Trophic niches of 563 thirteen damselfishes (Pomacentridae) at the Grand Recif of Toliara, Madagascar. Ichthyological 564 Reserch 56: 10-17

565

566 Froukh T, Kochzius M. 2008. Species boundaries and evolutionary lineages in the blue green 567 damselfishes Chromis viridis and Chromis atripectoralis (Pomacentridae). Journal of Fish 568 Biology 72: 451-457

569

570 Gainsford A, Herwerden L, Jones GP. 2015. Hierarchical behaviour, habitat use and species

571 size differences shape evolutionary outcomes of hybridization in a coral reef fish. Journal of 572 Evolutionary Biology 28: 205-222

573

574 Gaither MR, Bowen BW, Bordenave TR, Rocha LA, Newman SJ, Gomez JA, van

575 Herwerden L, Craig MT. 2011. Phylogeography of the reef fish Cephalopholis argus

576 (Epinephelidae) indicates Pleistocene isolation across the Indo-Pacific Barrier with

577 contemporary overlap in the Coral Triangle. BMC evolutionary biology 11: 189

578 
579 Goodheart JA, Bazinet AL, Valdés Á, Collins AG, Cummings MP 2017. Prey preference

580 follows phylogeny: evolutionary dietary patterns within the marine gastropod group

581 Cladobranchia (Gastropoda: Heterobranchia: Nudibranchia). BMC evolutionary biology 17: 221

582

583 Gutiérrez-Tapia P, Palma RE. 2016. Integrating phylogeography and species distribution

584 models: cryptic distributional responses to past climate change in an endemic rodent from the

585 central Chile hotspot. Diversity and Distributions 22: 638-650

586

587 Hare MP. 2001. Prospects for nuclear gene phylogeography. Trends in Ecology \& Evolution 16:

$588 \quad 700-706$

589

590

Hébert JB, Scheffer SJ, Hawthorne DJ. 2016. Evidence for ecological speciation via a host

591 shift in the holly leaf miner, Phytomyza glabricola (Diptera: Agromyzidae). Ecology and

592 Evolution 6: 6565-6577

593

594 He S, Johansen JL, Hoey AS, Pappas MK, Berumen ML. 2017. Molecular confirmation of 595 hybridization between Dascyllus reticulatus $\times$ Dascyllus aruanus from the Great Barrier Reef.

596 Marine Biodiversity, 1-10

597

598 Hubert N, Meyer CP, Bruggemann HJ, Guérin F, Komeno RJL, Espiau B, Causse R, 599

Williams JT. Planes S. 2012. Cryptic diversity in Indo-Pacific coral-reef fishes revealed by

600 DNA-barcoding provides new support to the centre-of-overlap hypothesis. PLoS one 7: e28987

601 
602 Hutchinson GE. 1978. An Introduction to Population Ecology (Yale Univ Press, New Haven, 603 CT).

604 Davies JT, Meiri S, Barraclough TG, Gittleman JL. 2007. Species coexistence and character 605 divergence across carnivores. Ecology letters 10: 146-152

606

607 Domingues VS, Bucciarelli G, Almada VC, Bernardi G. 2005. Historical colonization and 608 demography of the Mediterranean damselfish, Chromis chromis. Molecular Ecology 14: 40516094063

610

611 Kalkvik HM, Stout IJ, Doonan TJ, Parkinson CL. 2012. Investigating niche and lineage 612 diversification in widely distributed taxa: phylogeography and ecological niche modeling of the 613 Peromyscus maniculatus species group. Ecography 35: 54-64

614

615 Knowlton N. 1993. Sibling species in the sea. Annual Review of Ecology and Systematics 24: $616 \quad 189-216$

617

618 Kocher TD, Conroy JA, McKaye KR, Stauffer JR. 1993. Similar morphologies of cichlid fish 619 in Lakes Tanganyika and Malawi are due to convergence. Molecular Phylogenetic and Evolution 620 2: $158-165$

621

622 Kozak KH, Wiens JJ. 2006. Does niche conservatism promote speciation? A case study in 623 North American salamanders. Evolution 60: 2604-2621 
625 Leaché AD, Koo MS, Spencer CL, Papenfuss TJ, Fisher RN, McGuire JA. 2009.

626 Quantifying ecological, morphological, and genetic variation to delimit species in the coast

627 horned lizard species complex (Phrynosoma). Proceedings of the National Academy of Sciences

628 106: $12418-12423$

629

630 Larkin AA, Blinebry SK, Howes C, Lin Y, Loftus SE, Schmaus CA, Zinser ER, Johnson Z

631 I. 2016. Niche partitioning and biogeography of high light adapted Prochlorococcus across

632 taxonomic ranks in the North Pacific. The ISME journal 10: 1555

633

634 Lessios HA. 2008. The Great American Schism: divergence of marine organisms after the rise of 635 the Central American isthmus. Annual Review of Ecology, Evolution, and Systematics 39: 63-91

636

637 Liu SYV, Dai C-F, Allen GR, Erdmann MV. 2012. Phylogeography of the neon damselfish

638 Pomacentrus coelestis indicates a cryptic species and different species origins in the West

639 Pacific Ocean. Marine Ecology Progress Series 458: 155-167

640

641 Liu SYV, Ho H-C, Dai C-F. 2014. A new species of Pomacentrus (Actinopterygii:

642 Pomacentridae) from Micronesia, with comments on its phylogenetic relationships. Zoological

643 Studies 52: 1-8

644

645 Liu SYV, Frederich B, Lavoué S, Chang J, Erdmann MV, Mahardika GN, Barber PH.

646 2018. Buccal venom gland associates with increased of diversification rate in the fang blenny

647 fish Meiacanthus (Blenniidae; Teleostei). Molecular phylogenetics and evolution 125: 138-146 
648

649 Lord J, Westoby M, Leishman M. 1995. Seed size and phylogeny in six temperate floras:

650 constraints, niche conservatism, and adaptation. The American Naturalist 146: 349-364

651

652 Marske K, Leschen R, Buckley T. 2012. Concerted versus independent evolution and the 653 search for multiple refugia: comparative phylogeography of four forest beetles. Evolution 66: $654 \quad 1862-1877$

655

656 Messmer V, Jones GP, Munday PL, Planes S. 2012. Concordance between genetic and species 657 diversity in coral reef fishes across the Pacific Ocean biodiversity gradient. Evolution 66: 3902$658 \quad 3917$

659

660

661

Miller M, Pfeiffer W, Schwartz T. 2010. Creating the CIPRES science gateway for inference of large phylogenetic trees. Gateway Computing Environments Workshop (GCE), 1-8

662

663

Moore WS. 1995. Inferring phylogenies from mtDNA variation: mitochondrial-gene trees

664 versus nuclear-gene trees. Evolution 49: 718-726

665

666

Palumbi SR. 1996. Nucleic acid II: the polymerase chain reaction. In: Hillis, D.M., Moritz, G.,

667 Mable, B.K. (eds.). Molecular Systematics. Sunderland, Mass.: Sinauer Associates, 205-247

668

669 Peterson AT, Soberón J, Sánchez-Cordero V. 1999. Conservatism of ecological niches in

670 evolutionary time. Science 285: $1265-1267$ 
671

672 Peterson AT, Sánchez-Cordero V, Soberon J, Bartley J, Buddemeier RW, Navarro-

673 Sigüenza AG. 2001. Effects of global climate change on geographic distributions of Mexican

674 Cracidae. Ecological modelling 144: 21-30

675

676 Prugnolle F, De Meeûs T. 2002. Inferring sex-biased dispersal from population genetic tools: a 677 review. Heredity 88,161

678

679 Puebla O, Bermingham E, Guichard F. Whiteman E. 2007. Colour pattern as a single trait 680 driving speciation in Hypoplectrus coral-reef fishes? Proceedings of the Royal Society B 274: $681 \quad 1265-1271$

682

683

Pyron RA, Burbrink FT. 2009. Lineage diversification in a widespread species: roles for niche 684 divergence and conservatism in the common king snake, Lampropeltis getula. Molecular 685 ecology 18: 3443-3457

686

687

Pyron RA, Costa GC, Patten MA, Burbrink FT. 2015. Phylogenetic niche conservatism and 688 the evolutionary basis of ecological speciation. Biological Reviews 90: 1248-1262

689

690

Quattrini AM, Georgian SE, Byrnes L, Stevens A, Falco R, Cordes EE. 2013. Niche

691 divergence by deep-sea octocorals in the genus Callogorgia across the continental slope of the 692 Gulf of Mexico. Molecular Ecology 22: 4123-4140

693 
694 Quattrini AM, Gómez CE, Cordes EE. 2017. Environmental filtering and neutral processes

695 shape octocoral community assembly in the deep sea. Oecologia 183: 221-236

696

697 Quenouille B, Bermingham E, Planes S. 2004. Molecular systematics of the damselfishes

698 (Teleostei: Pomacentridae): Bayesian phylogenetic analyses of mitochondrial and nuclear DNA 699 sequences. Molecular phylogenetics and evolution 31: 66-88

700

701

702

Rambaut A, Drummond AJ. 2014. BEAST 2: A Software Platform for Bayesian Evolutionary Analysis. PLoS Computational Biology 10: e1003537

703

704

Randall HA, Allen GR. 1977. A revision of the damselfish genus Dascyllus (Pomacentridae) 705 with the description of a new species. Records of the Australian Museum 31: 349-385

706

707

708

Randall JE. 1998. Zoogeography of shore fishes of the Indo-Pacific region. Zoological Studies 37: $227-268$

709

710

Robinson O, Dylus D, Dessimoz C. 2016. Phylo.io: Interactive viewing and compar- ison of

711 large phylogenetic trees on the web. Molecular Biology and Evolution 33: 2163-2166

712

713 Rocha LA, Craig MT, Bowen BW. 2007. Phylogeography and the conservation of coral reef

714 fishes. Coral Reefs 26: 501-512

715 
716

717

718

719

720

721

722

723

724

725

726

727

728

729

730

731

732

733

734

735

736

737 738

Ronquist F, Teslenko M, Van Der Mark P, Ayres DL, Darling A, Höhna S, Larget B, Liu L, Huelsenbeck, JP. 2012. MrBayes 3.2: efficient Bayesian phylogenetic inference and model choice across a large model space. Systematic Biology 61: 539-542

Sbrocco EJ, Barber PH. 2013. MARSPEC: ocean climate layers for marine spatial ecology. Ecology 94: 979-979

Schorr G, Holstein N, Pearman PB, Guisan A, Kadereit JW. 2012. Integrating species distribution models (SDMs) and phylogeography for two species of Alpine Primula. Ecology and Evolution 2: 1260-1277

Siddall M, Rohling EJ, Almogi-Labin A, Hemleben C, Meischner D, Schmelzer I, Smeed DA. 2003. Sea-level fluctuations during the last glacial cycle. Nature 423: 853

\section{Simmonds SE, Chou V, Cheng SH, Rachmawati R, Calumpong HP, Mahardika GN,}

Barber PH. 2018. Evidence of host-associated divergence from coral-eating snails (genus Coralliophila) in the Coral Triangle. Coral Reefs 37: 355-371

Stamatakis A. 2014. RAxML version 8: a tool for phylogenetic analysis and post-analysis of large phylogenies. Bioinformatics 30: 1312-1313

Tamura K, Stecher G, Peterson D, Filipski A, Kumar S. 2013. MEGA6: molecular evolutionary genetics analysis version 6.0. Molecular Biology and Evolution 30: 2725-2729 
739 Tang QY, Liu SQ, Yu D, Liu HZ, Danley PD. 2012. Mitochondrial capture and incomplete

740 lineage sorting in the diversification of balitorine loaches (Cypriniformes, Balitoridae) revealed

741 by mitochondrial and nuclear genes. Zoologica Scripta 41: 233-247

742

743 Thompson JD, Higgins DG, Gibson TJ. 1994. CLUSTAL W: improving the sensitivity of

744 progressive multiple sequence alignment through sequence weighting, position-specific gap

745 penalties and weight matrix choice. Nucleic Acids Research 22: 4673-4680

746

747

Tyberghein L, Verbruggen H, Pauly K, Troupin C, Mineur F, De Clerck O. 2012. Bio-

748 ORACLE: A global environmental dataset for marine species distribution modelling. Global

749 Ecology and Biogeography 21: 272-281

750

751

Van Der Meer MH, Jones GP, Hobbs J-PA, van Herwerden L. 2012. Historic hybridization

752

and introgression between two iconic Australian anemone fish and contemporary patterns of

753

population connectivity. Ecology and Evolution 2: 1592-1604

754

755 Victor BC. 2015. How many coral reef fish species are there? Cryptic diversity and the new

756 molecular taxonomy. Ecology of Fishes on Coral Reefs. Cambridge University Press,

757 Cambridge, United Kingdom, 76-87

758

759 Voris HK. 2000. Maps of Pleistocene sea levels in Southeast Asia: shorelines, river systems and

760 time durations. Journal of Biogeography 27: 1153-1167 
761 Wabnitz C. 2003. From ocean to aquarium: the global trade in marine ornamental species (No.

762 17). UNEP/Earthprint

763

764 Waldrop E, Hobbs JPA, Randall, JE, DiBattista JD, Rocha LA, Kosaki RK, Berumen ML,

765 Bowen BW. 2016. Phylogeography, population structure and evolution of coral-eating

766 butterflyfishes (Family Chaetodontidae, genus Chaetodon, subgenus Corallochaetodon). Journal

767 of Biogeography 43: 1116-1129

768

769

Warren DL, Glor RE, Turelli M. 2008. Environmental niche equivalency versus conservatism:

770 quantitative approaches to niche evolution. Evolution 62: 2868-2883

771

772 Westneat MW, Alfaro ME. 2005. Phylogenetic relationships and evolutionary history of the 773 reef fish family Labridae. Molecular phylogenetics and evolution 36: 370-390

774

775

776

Whitney JL, Donahue MJ, Karl SA. 2018. Niche divergence along a fine-scale ecological gradient in sympatric color morphs of a coral reef fish. Ecosphere 9: e02015

777

778

Wiens JJ. 2004. Speciation and ecology revisited: phylogenetic niche conservatism and the 779 origin of species. Evolution 58: 193-197

780

781 Wiens JJ, Graham CH. 2005. Niche conservatism: integrating evolution, ecology, and 782 conservation biology. Annual Review of Ecology, Evolution, and Systematics 36: 519-539 
784 Wisz MS, Hijmans RJ, Li J, Peterson AT, Graham CH, Guisan A. 2008. Effects of sample

785 size on the performance of species distribution models. Diversity and Distributions 14: 763-773

786 
Figure 1

Map of sampling locations. Abbreviations of the locations are given in Table 1 , and the number in the parenthesis is the sample size

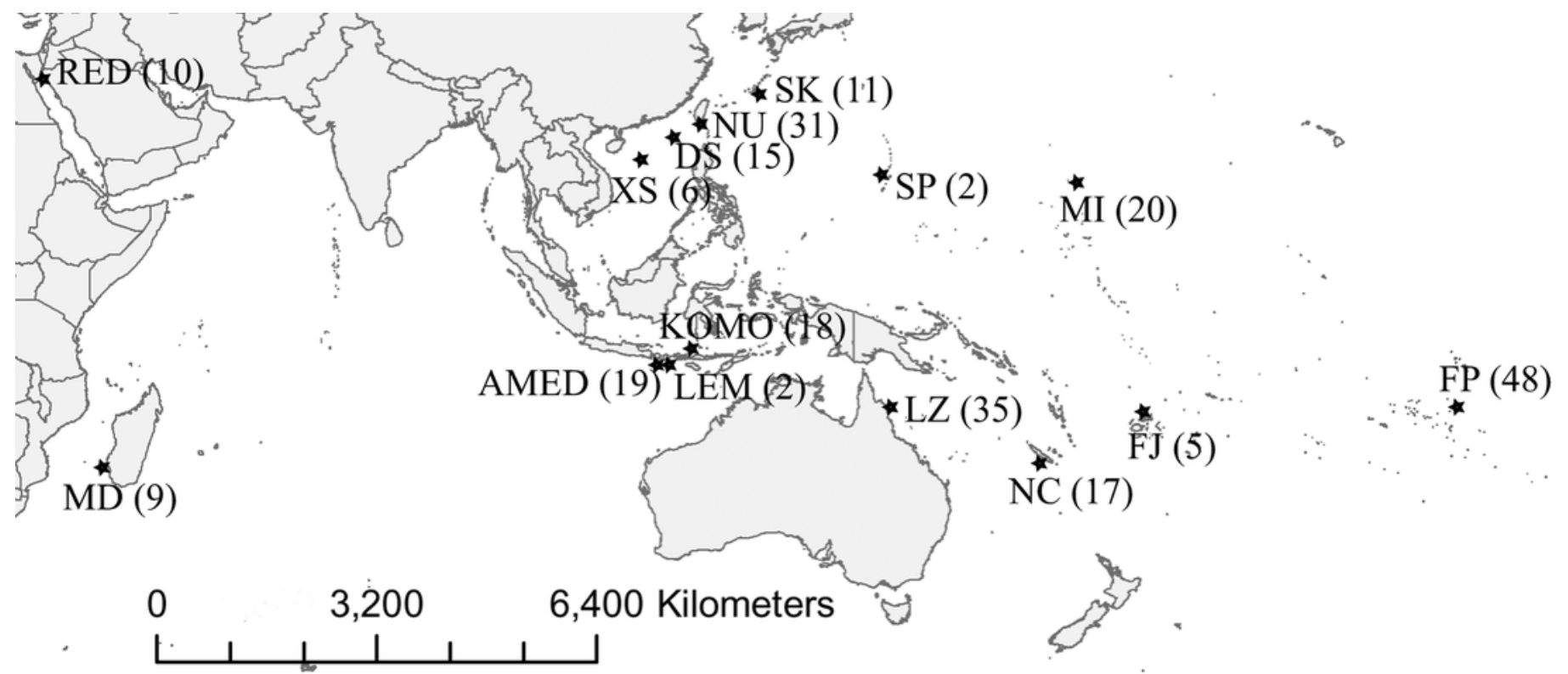




\section{Figure 2}

Bayesian phylogenetic tree $(A, B)$ and corresponding haplotype network $(C, D)$ based on two genetic markers including $C y t b$ and Rag2.

Nodes are presented only for those with bootstrap scores $>85 \%$ majority rule for maximum likelihood and $>90 \%$ majority probabilities for Bayesian probability values (BI/ML). For the Haplotype network, different colors indicate different clades (e.g., white $=$ Chromis viridis Clade A, gray = Chromis viridis Clade B, and black = Red Sea), mutation step larger than 20 were denoted by hatch marks with number of mutation steps 


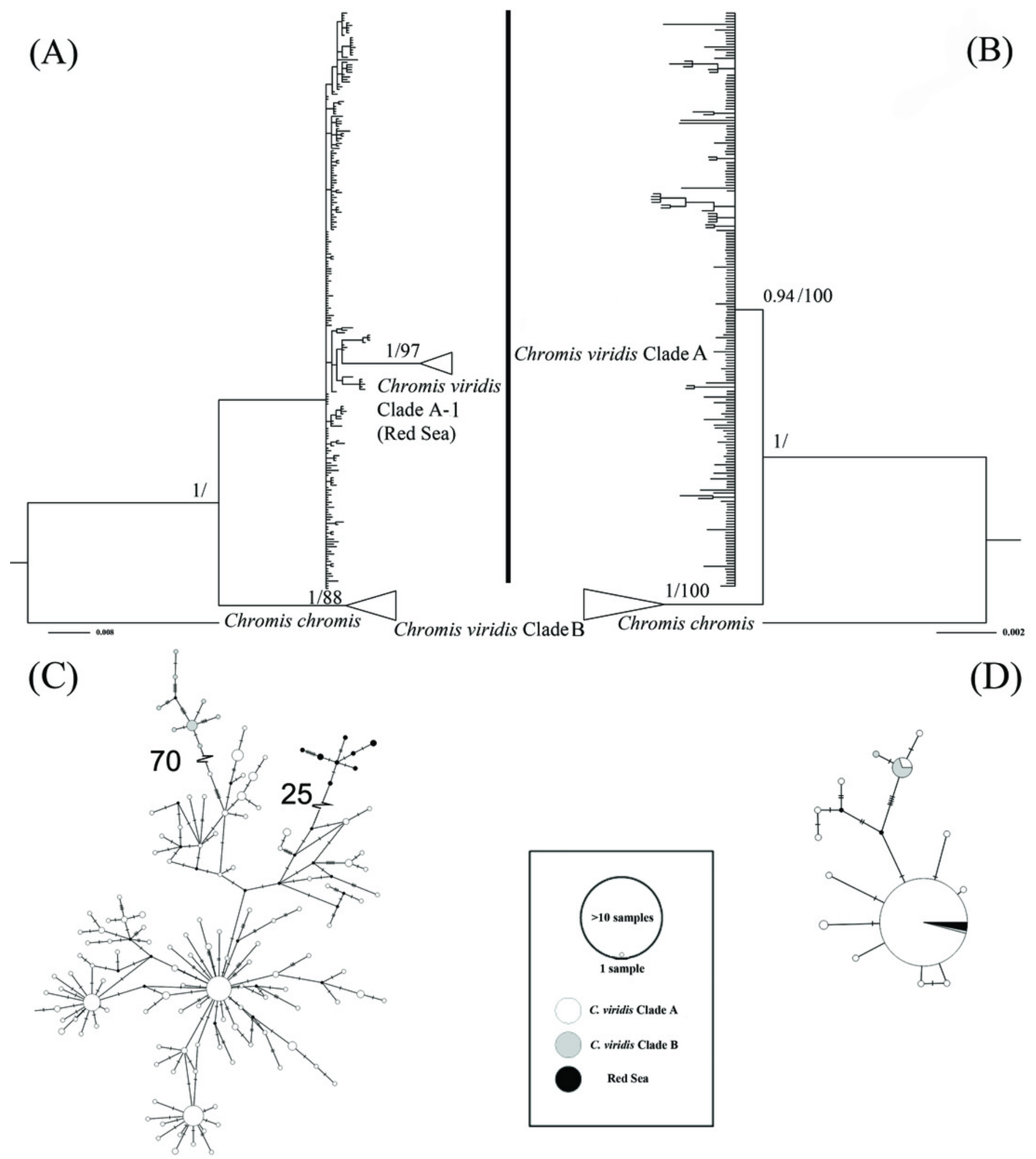


Figure 3

Time-tree of cryptic lineages among Chromis viridis obtained from BEAST.

With a 3.1 MYA time constraint on the node between Chromis atrilobata and Chromis multilineata (Quenouille et al., 2004). Horizontal grey bars at nodes indicate $95 \%$ posterior probability densities (HPD) intervals of age.

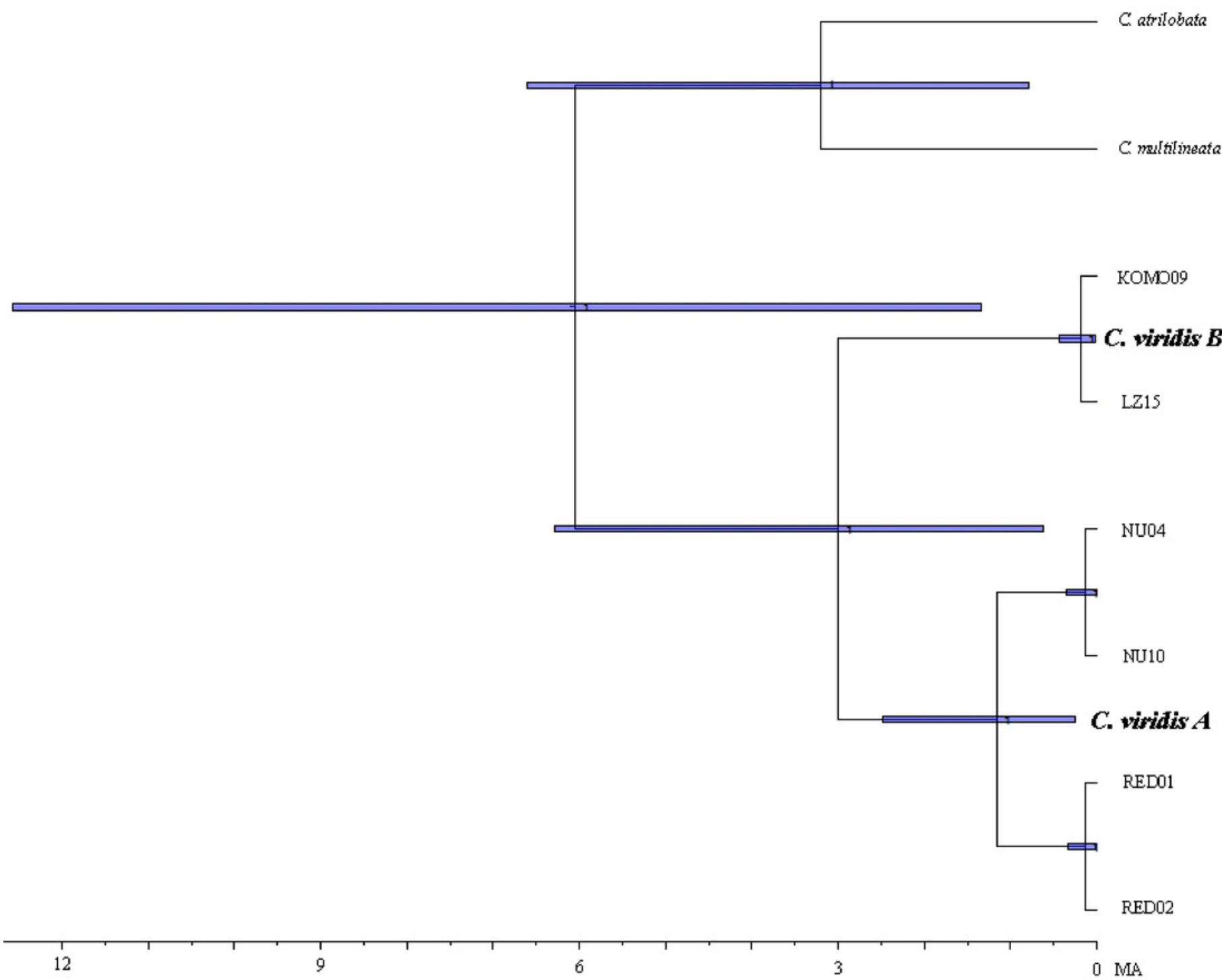




\section{Figure 4}

Non-metric multidimensional scaling (NMDS) plot of the 15 sampling sites.

The two NMDS axes (NMDS1 and NMDS2) represent environmental gradients defined by the 11 environmental factors examined across the sites. The convex hulls for the sampling sites where $C$. viridis $A$ and $C$. viridis $B$ were found are shown in red and blue, respectively. Please see the legend of Fig. 1 for the abbreviation of the site names. 


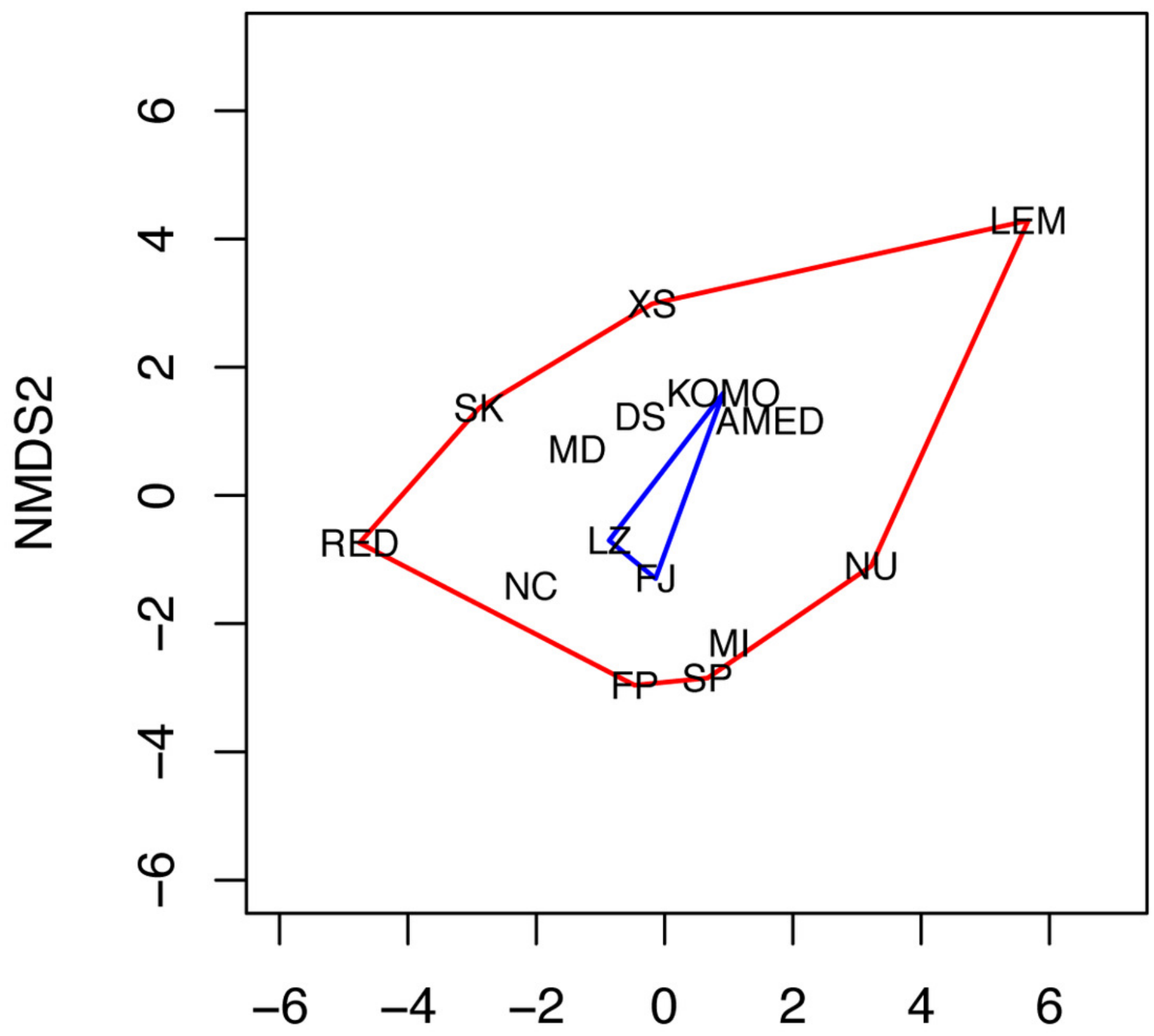

NMDS1 


\section{Table $\mathbf{1}$ (on next page)}

Sampling locations and diversity indices based on Cytb sequences (911bp) in 15 populations of Chromis viridis from the Indo-Pacific.

Abbreviations are as follows: $\mathrm{N}=$ sample size, $\mathrm{nh}=$ number of haplotype, $\mathrm{h}=$ haplotype diversity, and $\pi=$ nucleotide diversity. 
1 Table 1. Sampling locations and diversity indices based on Cytb sequences ( $911 \mathrm{bp})$ in 15 populations of Chromis viridis from the

2 Indo-Pacific. Abbreviations are as follows: $\mathrm{N}=$ sample size, $\mathrm{nh}=$ number of haplotype, $\mathrm{h}=$ haplotype diversity, and $\pi=$ nucleotide

3 diversity.

\begin{tabular}{|c|c|c|c|c|c|c|c|c|c|}
\hline \multirow[b]{2}{*}{ Abb. } & \multirow[b]{2}{*}{ Location } & \multicolumn{6}{|c|}{ Cytb } & \multicolumn{2}{|l|}{ Rag2 } \\
\hline & & $\mathrm{N}$ & $\mathrm{nh}$ & $\mathrm{h} \pm \mathrm{SD}$ & $\pi \pm \mathrm{SD}$ & $\mathrm{n}$ & $\mathrm{n} h$ & $h \pm \mathrm{SD}$ & $\pi \pm \mathrm{SD}$ \\
\hline RED & Eliat, Israel & 10 & 8 & $0.956 \pm 0.059$ & $0.004 \pm 0.002$ & 6 & 6 & $1.000 \pm 0.096$ & $0.003 \pm 0.002$ \\
\hline MD & Toliara, Madagascar & 9 & 6 & $0.889 \pm 0.091$ & $0.007 \pm 0.004$ & 9 & 9 & $1.000 \pm 0.052$ & $0.005 \pm 0.003$ \\
\hline AMED & Amed, Bali, Indonesia & 19 & 14 & $0.953 \pm 0.036$ & $0.007 \pm 0.004$ & 18 & 17 & $0.994 \pm 0.021$ & $0.004 \pm 0.002$ \\
\hline LEM & Nusa Lembongan, Bali, Indonesia & 2 & 2 & $1.000 \pm 0.500$ & $0.003 \pm 0.004$ & 2 & 2 & $1.000 \pm 0.500$ & $0.006 \pm 0.006$ \\
\hline KOMO & Komodo, Indonesia & 18 & 11 & $0.882 \pm 0.064$ & $0.014 \pm 0.007$ & 18 & 18 & $1.000 \pm 0.019$ & $0.005 \pm 0.003$ \\
\hline XS & Xisha, China & 6 & 6 & $1.000 \pm 0.096$ & $0.006 \pm 0.004$ & 8 & 8 & $1.000 \pm 0.063$ & $0.004 \pm 0.003$ \\
\hline DS & Dongsha, Taiwan & 15 & 11 & $0.933 \pm 0.054$ & $0.005 \pm 0.003$ & 15 & 15 & $1.000 \pm 0.024$ & $0.005 \pm 0.003$ \\
\hline $\mathrm{NU}$ & NPP III Inlet, Taiwan & 31 & 24 & $0.972 \pm 0.020$ & $0.005 \pm 0.003$ & 23 & 23 & $1.000 \pm 0.013$ & $0.004 \pm 0.002$ \\
\hline SK & SesokoIsland, Japan & 11 & 9 & $0.946 \pm 0.066$ & $0.005 \pm 0.003$ & 11 & 11 & $1.000 \pm 0.034$ & $0.005 \pm 0.003$ \\
\hline SP & Saipan, USA & 2 & 1 & $0.000 \pm 0.000$ & $0.000 \pm 0.000$ & 2 & 2 & $1.000 \pm 0.500$ & $0.000 \pm 0.000$ \\
\hline MI & $\begin{array}{l}\text { Marshall Island, R.O. Marshall } \\
\text { Islands }\end{array}$ & 20 & 15 & $0.942 \pm 0.043$ & $0.005 \pm 0.003$ & 13 & 13 & $1.000 \pm 0.030$ & $0.004 \pm 0.003$ \\
\hline $\mathrm{NC}$ & New Caledonia, French & 17 & 16 & $0.993 \pm 0.023$ & $0.006 \pm 0.003$ & 15 & 15 & $1.000 \pm 0.024$ & $0.004 \pm 0.002$ \\
\hline $\mathrm{LZ}$ & Lizard Island, Australia & 35 & 26 & $0.968 \pm 0.020$ & $0.039 \pm 0.019$ & 35 & 35 & $0.998 \pm 0.007$ & $0.009 \pm 0.005$ \\
\hline FJ & Fiji & 5 & 5 & $1.000 \pm 0.127$ & $0.054 \pm 0.033$ & 4 & 4 & $1.000 \pm 0.177$ & $0.015 \pm 0.011$ \\
\hline FP & Moorea Island, French Polynesia & 48 & 21 & $0.7846 \pm 0.0612$ & $0.0028 \pm 0.0016$ & 39 & 35 & $0.9933 \pm 0.0080$ & $0.0042 \pm 0.0025$ \\
\hline
\end{tabular}




\section{Table 2 (on next page)}

Mann-Whitney $U$ tests for the environmental differences between presence locations of clade $A$ and those of clade $B$, and between presence and absence locations of clade $A$. 
1 Table 2. Mann-Whitney $U$ tests for the environmental differences between presence locations of

2 clade A and those of clade B, and between presence and absence locations of clade A.

\begin{tabular}{|c|c|c|c|c|c|c|c|}
\hline \multirow{2}{*}{$\begin{array}{l}\text { Environmental } \\
\text { Factor }\end{array}$} & \multirow{2}{*}{$\begin{array}{l}\text { A presence (Mean } \\
\pm \mathrm{SD})\end{array}$} & \multirow{2}{*}{$\begin{array}{l}\text { B presence (Mean } \\
\pm \mathrm{SD})\end{array}$} & \multirow{2}{*}{$\begin{array}{l}\text { A absence (Mean } \\
\pm \mathrm{SD})\end{array}$} & \multicolumn{2}{|c|}{$\begin{array}{l}\text { A presence vs. B } \\
\text { presence }\end{array}$} & \multicolumn{2}{|c|}{$\begin{array}{l}\text { A presence vs. A } \\
\text { absence }\end{array}$} \\
\hline & & & & $\mathrm{U}$ & P-value & $\mathrm{U}$ & P-value \\
\hline Temperature $\left({ }^{\circ} \mathrm{C}\right)$ & $27.44 \pm 0.86$ & $27.15 \pm 1.35$ & $27.08 \pm 1.47$ & 20.5 & 0.86 & 20 & 0.84 \\
\hline Salinity (PSS) & $34.31 \pm 0.86$ & $34.55 \pm 1.43$ & $34.61 \pm 1.57$ & 22.5 & 1 & 18 & 1 \\
\hline $\begin{array}{l}\text { Current velocity } \\
\left(\mathrm{m}^{-1}\right)\end{array}$ & $0.09 \pm 0.06$ & $0.13 \pm 0.19$ & $0.14 \pm 0.21$ & 23.5 & 0.95 & 17 & 0.95 \\
\hline Nitrate $\left(\mathrm{mol} \cdot \mathrm{m}^{-3}\right)$ & $0.007 \pm 0.009$ & $0.11 \pm 0.31$ & $0.13 \pm 0.34$ & 25.5 & 0.77 & 15 & 0.73 \\
\hline $\begin{array}{l}\text { Phosphate }\left(\mathrm{mol} \cdot \mathrm{m}^{-}\right. \\
\text {3) }\end{array}$ & $0.25 \pm 0.05$ & $0.23 \pm 0.06$ & $0.22 \pm 0.06$ & 18.5 & 0.68 & 22 & 0.63 \\
\hline Silicate $\left(\mathrm{mol} \cdot \mathrm{m}^{-3}\right)$ & $3.57 \pm 1.99$ & $3.74 \pm 1.85$ & $3.79 \pm 1.90$ & 23.5 & 0.95 & 17 & 0.95 \\
\hline $\begin{array}{l}\text { Dissolved } \\
\text { molecular oxygen } \\
\left(\mathrm{mol} \cdot \mathrm{m}^{-3}\right)\end{array}$ & $203.15 \pm 1.50$ & $203.65 \pm 3.34$ & $203.78 \pm 3.70$ & 22.5 & 1 & 18 & 1 \\
\hline Iron $\left(\mathrm{umol} \cdot \mathrm{m}^{-3}\right)$ & $0.001 \pm 0.0003$ & $0.0007 \pm 0.0005$ & $0.0006 \pm 0.0005$ & 10.5 & 0.17 & 30 & 0.1 \\
\hline $\begin{array}{l}\text { Chlorophyll } \\
\left(\mathrm{mg} \cdot \mathrm{m}^{-3}\right)\end{array}$ & $0.14 \pm 0.04$ & $0.15 \pm 0.12$ & $0.15 \pm 0.13$ & 18.5 & 0.68 & 22 & 0.63 \\
\hline $\begin{array}{l}\text { Phytoplankton } \\
\left(\text { umol } \cdot \mathrm{m}^{-3}\right)\end{array}$ & $1.19 \pm 0.16$ & $1.14 \pm 0.48$ & $1.13 \pm 0.54$ & 15.5 & 0.44 & 25 & 0.36 \\
\hline $\begin{array}{l}\text { Primary } \\
\text { productivity }\left(\mathrm{g} \cdot \mathrm{m}^{-}\right. \\
\left.{ }^{3} \cdot \text { day }^{-1}\right)\end{array}$ & $0.006 \pm 0.003$ & $0.006 \pm 0.008$ & $0.007 \pm 0.009$ & 17.5 & 0.59 & 23 & 0.54 \\
\hline
\end{tabular}

